\title{
Leiomyomatosis peritonealis disseminata in a nonpregnant woman
}

\section{Nulligravid olguda leiomyomatosis peritonealis disseminata}

\author{
(D) Abdullah Aydın ${ }^{1}$, Tuçe Söylemez ${ }^{1}$, Ateş Karateke ${ }^{2}$, Mesut Polat ${ }^{2}$, Burçin Rabia Girgin ${ }^{1}$ \\ ${ }^{1}$ İstanbul Medeniyet University Faculty of Medicine, Department of Pathology, İstanbul, Turkey \\ ${ }^{2}$ İstanbul Medeniyet University Faculty of Medicine, Department of Obstetrics and Gynecology, İstanbul, Turkey
}

Keywords: Nulligravida, leiomyomatosis peritonealis disseminata, abdominal mass

Anahtar Kelimeler: Nulligravid, leiomyomatosis peritonealis disseminata, abdominal kitle

\section{To the Editor,}

Leiomyomatosis peritonealis disseminata (LPD) is a rare entity characterized by the presence of multiple, small nodules of smooth muscle on the peritoneal and omental surfaces $^{(1)}$. LPD was first described by Wilson and Peale in 1952. Fewer than 140 cases have been reported so $\mathrm{far}^{(1,2)}$. It is generally seen in women at reproductive ages; however, there are cases reported in men ${ }^{(2)}$. In most cases, there is an underlying condition such as pregnancy or exogenous hormone replacement, which may cause elevated estrogen levels ${ }^{(3)}$. Here, we present a case of LPD, which developed in a nulligravida woman who received no exogenous hormone therapy. A nulligravida women aged 36 years presented to the gynecology department of İstanbul Göztepe Training and Research Hospital with lower abdominal pain, which she had had for over a year. In her history, there was no history of chronic disease or drug use. She had regular menstrual cycles. In the laboratory evaluation, cancer antigen (CA)-125 was $43.9 \mathrm{U} / \mathrm{mL}$ and serum estradiol and progesterone levels were within normal range. A computed tomography scan revealed a mass lesion, which filled the pelvis completely and extended to the peritoneum. Thus, she underwent a laparotomy for removal of the mass lesion. In the laparotomy, a multi-nodular, solid mass lesion originating from the anterior serosal surface of the uterus was seen (Figure 1A, B). Both adnexa were unremarkable. In addition, multiple, solid nodules ( 2 or $3 \mathrm{~cm}$ in size) were present over the peritoneum. There was diffuse, free fluid in abdomen. Mesenchymal neoplasm was primarily considered in the patient who desired to preserve fertility, and therefore a frozen examination was not performed. Fertility was preserved and only excision of masses over the peritoneum and originating from the anterior serosal surface of uterus was performed. Gross pathology showed a multinodular mass lesion $(30 \times 24 \times 8 \mathrm{~cm}$ in size) that consisted of multiple, fibrillary nodules with a creamy-white appearance. On microscopic examination, there were bland smooth muscle cells resembling ordinary leiomyoma without atypia, necrosis or mitosis (Figure 1C, D). Tumor cells were reactive for estrogen receptor, progesterone receptor, desmin, alpha smooth muscle actin, and caldesmon (Figure 1E, F). The Ki-67 index was $<1$. No S-100, AE1/AE3, cam 5.2 or CD117 expression was observed in the tumor cells. Histopathologic and immunohistochemical findings favored smooth muscle tumor.

LPD is a rare lesion that is mainly seen in young-middle aged women who have hormonal changes due to pregnancy ${ }^{(2,3)}$. Although its pathophysiology is not fully understood, it may be classified in 4 categories including hormonal, iatrogenic, genetic, and subperitoneal mesenchymal cell metaplasia. Although some authors suggest that it arises from subserosal cells with myofibroblastic or smooth muscle cell metaplasia, Travassoli and Norris support the hormonal theory given that most patients are pregnant women or have a history of longterm oral contraceptive use, and that tumor cells express estrogen and progesterone receptors ${ }^{(4)}$. The vast majority of

Address for Correspondence/Yazışma Adresi: Abdullah Aydın, MD,

İstanbul Medeniyet University Faculty of Medicine, Department of Pathology, İstanbul, Turkey

Phone: +90 5054579921 E-mail: abaydin42@yahoo.com ORCID ID: orcid.org/0000-0002-5181-9409

Received/Geliş Tarihi: 09.06.2018 Accepted/Kabul Tarihi: 17.09.2018

${ }^{\circledR}$ Copyright 2018 by Turkish Society of Obstetrics and Gynecology

Turkish Journal of Obstetrics and Gynecology published by Galenos Publishing House. 
patients are asymptomatic; however, non-specific findings such as abdominal pain, vaginal bleeding or intestinal obstruction caused by the mass lesion may be present in symptomatic patients. We believe that the number of patients with LPD is underestimated in the literature because most cases are asymptomatic ${ }^{(3)}$.

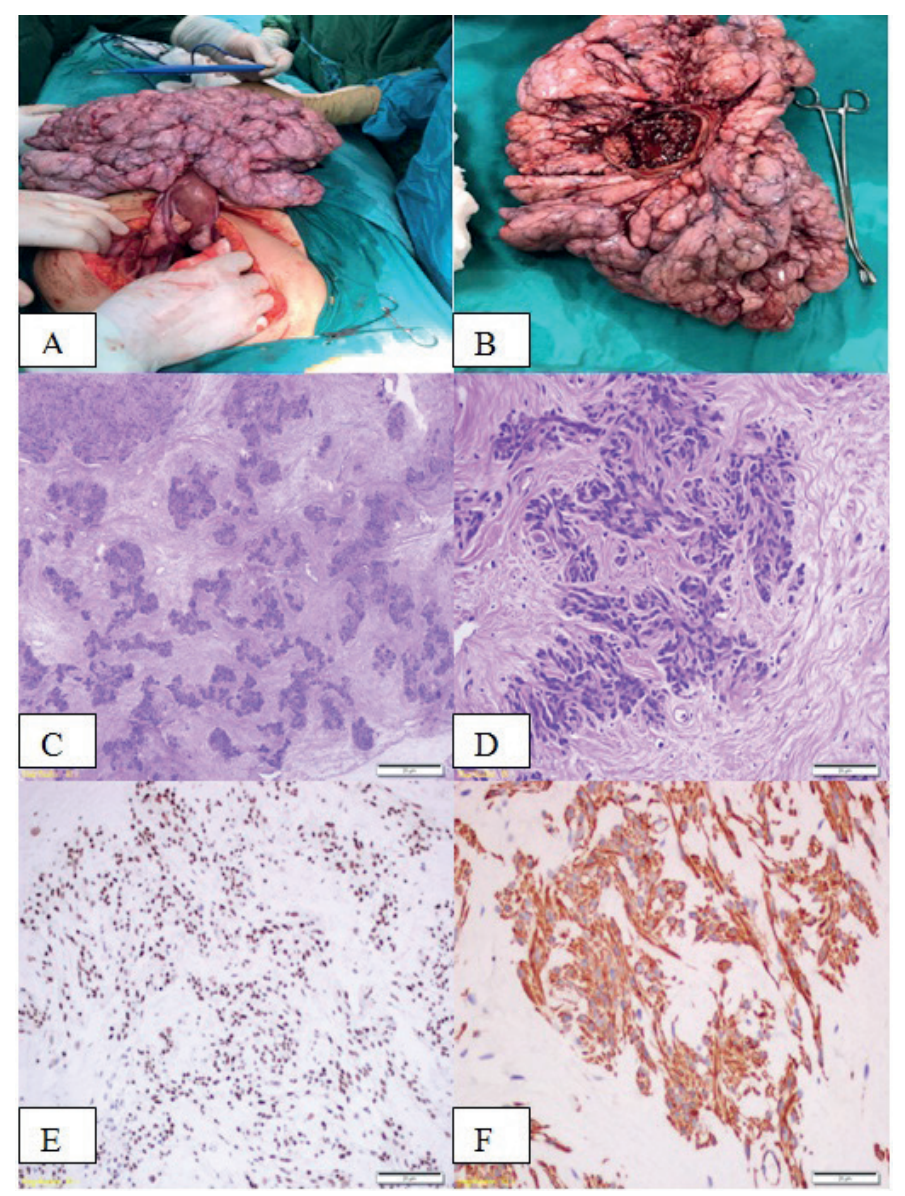

Figure 1. A-F) Intraoperative photography showed multinodular solid mass that had originated from anterior serosal surface of uterus (A, B), microscopic examination revealed smooth muscle proliferation (hematoxylin and eosin Cx40, Dx200), estrogen receptor and caldesmon positivity in tumor cells (E and F x200)
In conclusion, in the differential diagnosis of this entity, peritoneal carcinomatosis and leiomyosarcoma should be considered $^{(5)}$. In our patient, peritoneal carcinomatosis was excluded by histopathologic findings and the absence of primary carcinoma, and leiomyosarcoma was excluded because of the lack of atypia, pleomorphism, necrosis, and high mitotic index ${ }^{(2)}$. LPD is a tumor with benign course in general, although there have been a few cases with malignant transformation ${ }^{(4,5)}$.

\section{Ethics}

Peer-review: Externally peer-reviewed.

\section{Authorship Contributions}

Surgical and Medical Practices: A.K., M.P., Concept: A.A., T.S., Design: A.A., A.K., Data Collection or Processing: T.S., B.R.G., Analysis or Interpretation: A.A., T.S., Literature Search: A.A., T.S., Writing: A.A., T.S., B.R.G.

Conflict of Interest: No conflict of interest was declared by the authors.

Financial Disclosure: The authors declared that this study received no financial support.

\section{References}

1. Al-Talib A, Tulandi T. Pathophysiology and Possible Iatrogenic Cause of Leiomyomatosis Peritonealis Disseminata. Gynecol Obstet Invest 2010;69:239-44

2. Yuri T, Kinoshita Y, Yuki M, Yoshizawa K, Emoto Y, Tsubura A. Leiomyomatosis Peritonealis Disseminata Positive for Progesterone Receptor. Am J Case Rep 2015;16:300-4.

3. Nucci MR, Quade BJ. Uterine Mesenchymal Tumors. In: Crum CP, Nucci MR, Lee KR, editors. Diagnostic gynecologic and obstetric pathology. Philadelphia: Elsevier Saunders; 2011:621-22.

4. Wu C, Zhang X, Tao X, Ding J, Hua K. Leiomyomatosis peritonealis disseminata: A case report and review of the literature. Mol Clin Oncol 2016:4:957-58

5. Psathas G, Zarokosta M, Zoulamoglou M, Chrysikos D, Thivaios I, Kaklamanos I, et al. Leiomyomatosis peritonealis disseminata: A case report and meticulous review of the literature. Int J Surg Case Rep 2017:40:105-8. 